\title{
A multicomponent system based on a blend of agroindustrial wastes for the simultaneous production of industrially applicable enzymes by solid-state fermentation
}

\author{
Andre OHARA ${ }^{1}$, Jessika Gonçalves dos SANTOS², Joelise Alencar Figueira ANGELOTTI ${ }^{2}$, \\ Paula de Paula Menezes BARBOSA², Fernanda Furlan Gonçalves DIAS ${ }^{2}$, Marcela Pavan BAGAGLI², \\ Hélia Harumi SATO², Ruann Janser Soares de CASTRO ${ }^{2 *}$
}

\begin{abstract}
This study reports the use of statistical mixture design as a tool for the simultaneous production of lipase, CMCase, $\alpha$-amylase, and $\beta$-glucosidase by Aspergillus niger under solid-state fermentation. Wheat bran, soybean meal, cottonseed meal, and orange peel were used as substrates, either individually or combined in different formulations, to study their synergistic or antagonistic effects on production of the enzymes. The highest lipase $\left(323 \mathrm{U} \mathrm{g}^{-1}\right)$ and CMCase $\left(10 \mathrm{U} \mathrm{g} \mathrm{g}^{-1}\right)$ activities were detected after $48 \mathrm{~h}$, while the maximum activities of $\alpha$-amylase $\left(18 \mathrm{U} \mathrm{g} \mathrm{g}^{-1}\right)$ and $\beta$-glucosidase $\left(15 \mathrm{U} \mathrm{g}^{-1}\right)$ occurred at 72 and $96 \mathrm{~h}$, respectively. Considering the substrate formulation, the ternary mixture of wheat bran (1/3), soybean meal (1/3), and cottonseed meal (1/3) was the most versatile, showing production of CMCase $\left(>5 \mathrm{U} \mathrm{g}^{-1}\right)$ and $\alpha$-amylase $\left(>8 \mathrm{U} \mathrm{g}^{-1}\right)$ at $24 \mathrm{~h}$, lipase $\left(>320 \mathrm{U} \mathrm{g}^{-1}\right)$ at $72 \mathrm{~h}$, and $\beta$-glucosidase $\left(>10 \mathrm{U} \mathrm{g}^{-1}\right)$ at $48 \mathrm{~h}$.
\end{abstract}

Keywords: industrial enzymes; solid-state fermentation; Aspergillus niger; agroindustrial wastes; mixture design.

Practical Application: The mixture design offers a powerful tool to formulate and optimize agroindustrial waste mixtures that can be used for the generation of several bio-based products. The given approach can be also expanded to studies regarding the analysis of agroindustrial wastes prices and availability, relating to the importance of specific components in the wastes, that can be added in controlled amounts as inducers, resulting in a rentable and effective formulation for simultaneous production of enzymes, vitamins, bioactive peptides, pigments, and other high added value products.

\section{Introduction}

Solid-state fermentation (SSF) has been applied as a promising and alternative technology for enzyme production. Compared with submerged fermentation, SSF has some attractive advantages, such as low risk of contamination, increased yield, low-cost substrate utilization, process simplicity, lower energy requirement, and decreased wastewater production. The processing of raw materials results in the generation of agroindustrial wastes that can be used as substrates in SSF. The production of industrial enzymes, such as lipases, proteases, cellulases, and $\alpha$-amylases, is an example of the potential application of wastes in SSF (Thomas et al., 2013; Martins et al., 2011).

SSF is also an attractive process for the cultivation of filamentous fungi because the solid substrates have characteristics similar to the natural fungal habitat, resulting in good growth and secretion of a wide range of enzymes (Castro \& Sato, 2015; Chen et al., 2014). Aspergillus niger strains have a recognized historical use in industrial processes as producers of extracellular lipases, proteases, and cellulases (Mahadik et al., 2002; Devi \& Kumar, 2017; Xue et al., 2015). In addition, microbial enzymes as lipase, cellulose, amylase and endo- $\beta$-1,4-glucanase (CMCase) have been replaced plant and animal enzymes and also been applied in many industries including foods, beverages, pharmaceuticals, detergents, textiles, leather, chemicals, biofuels, animal feed, personal care, pulp and paper, diagnostics, and therapy (Treichel et al., 2010; Behera \& Ray, 2016; Dar et al., 2015).

Different agroindustrial wastes, such as soybean meal, wheat bran, corncob, rice husk, and gingelly oil cake, have been used for enzyme production under SSF by $A$. niger (Mahadik et al., 2002; Damaso et al., 2008; Colla et al., 2010). The application of statistical mixture design using different formulations offers the possibility to study the interactions of the different components and to analyze how these interactions will affect a specific response (Castro \& Sato, 2013).

The aims of this study were to verify the interactions among different agroindustrial wastes and to modulate the media compositions by the balance of their chemical components. Therefore, different agroindustrial wastes were used as substrates, either individually or combined in different mixtures and proportions, to select the most appropriate formulation for the simultaneous production of lipase, CMCase, $\alpha$-amylase, 
and $\beta$-glucosidase by $A$. niger LBA 02 under SSF using a simplex-lattice mixture design.

\section{Materials and methods}

\subsection{Microorganism culture}

The strain used in this study was A. niger LBA 02 , previously selected as a proteolytic strain from the culture collection of the Laboratory of Food Biochemistry, School of Food Engineering, University of Campinas, Brazil. To produce fungal spores, the microorganism was inoculated into a medium composed of $10 \mathrm{~g}$ of wheat bran and $5 \mathrm{~mL}$ of a solution containing 1.7\% $(\mathrm{w} / \mathrm{v}) \mathrm{NaHPO}_{4}$ and $2.0 \%(\mathrm{w} / \mathrm{v})\left(\mathrm{NH}_{4}\right)_{2} \mathrm{SO}_{4}$ and incubated for 3 days at $30^{\circ} \mathrm{C}$.

\subsection{Enzyme production}

Wheat bran, soybean meal, and cottonseed meal were kindly provided by Bunge Foods S/A (Gaspar, Brazil). Orange peel was purchased from a local market and was ground, washed three and dried at $50{ }^{\circ} \mathrm{C}$ for $24-48 \mathrm{~h}$. These agroindustrial wastes were used for the production of lipase, CMCase, $\alpha$-amylase, and $\beta$-glucosidase by $A$. niger LBA 02 . Enzyme production was performed under SSF using individual substrates, or their binary, ternary, or quaternary mixtures in various proportions, in $250 \mathrm{~mL}$ Erlenmeyer flasks containing $20 \mathrm{~g}$ of medium. The initial cultivation parameters were $50 \%$ moisture in dry basis, temperature set at $30{ }^{\circ} \mathrm{C}$, and an inoculum level of $10^{7}$ spores/g. Enzyme activities were determined at $24 \mathrm{~h}$ intervals during $96 \mathrm{~h}$ of fermentation. The crude extracts were obtained by adding $100 \mathrm{~mL}$ of distilled water to the fermented medium, manually homogenizing the mixture with a glass rod, and then maintaining it at rest for $1 \mathrm{~h}$. The solutions were filtered through a filter membrane (Whatman $n^{\circ} 1$ ) to obtain enzyme solutions free of any solid material.

\subsection{Statistical mixture design}

The statistical mixture design was used to obtain the optimum mixture of agroindustrial wastes for maximum enzyme production and to evaluate the interaction effects in a blend of components. A four-component augmented simplex-lattice design was used, with each component being studied at six levels; namely, 0 (0\%), 1/8 (12.5\%), 1/4 (25\%), 1/2 (50\%), 5/8 (62.5\%), and $1(100 \%)$ (Table 1$)$.

Special cubic regression models were fitted to the experimental data for the response variable $Y$ as a function of the independent variables, as shown in Equation 1:

$Y i=\sum_{i=1}^{q} \beta i X i+\sum \sum_{i<j}^{q} \beta i j X i X j+\sum \sum_{i<j<k}^{q} \sum \beta i j k X i X j X k$

where $Y_{\mathrm{i}}$ is the predicted response; $q$ represents the number of components in the mixture; $X_{\mathrm{i}}, X_{\mathrm{j}}$, and $X_{\mathrm{k}}$ are the coded independent variables; $\beta_{i}$ is the regression coefficient for each linear effect term; and $\beta_{\mathrm{ij}}$ and $\beta_{\mathrm{ijk}}$ are the binary and ternary interaction effect terms, respectively. The coefficient of determination $R^{2}$ (acceptable $>0.85$ ) and the $F$ test (analysis of variance [ANOVA]) were used to verify the quality of fit of the models. Statistica 10 software from Statsoft Inc. (Tulsa,
Table 1. Matrix of the four-component augmented simplex-lattice design.

\begin{tabular}{|c|c|c|c|c|}
\hline \multirow{3}{*}{ Run } & \multicolumn{4}{|c|}{ Independent variables } \\
\hline & $\begin{array}{l}\text { Wheat } \\
\text { bran }\end{array}$ & $\begin{array}{c}\text { Soybean } \\
\text { meal }\end{array}$ & $\begin{array}{c}\text { Cottonseed } \\
\text { meal }\end{array}$ & $\begin{array}{c}\text { Orange } \\
\text { peel }\end{array}$ \\
\hline & $\mathrm{x}_{1}$ & $\mathrm{x}_{2}$ & $\mathrm{x}_{3}$ & $\mathrm{x}_{4}$ \\
\hline 1 & 1 & 0 & 0 & 0 \\
\hline 2 & 0 & 1 & 0 & 0 \\
\hline 3 & 0 & 0 & 1 & 0 \\
\hline 4 & 0 & 0 & 0 & 1 \\
\hline 5 & $1 / 2$ & $1 / 2$ & 0 & 0 \\
\hline 6 & $1 / 2$ & 0 & $1 / 2$ & 0 \\
\hline 7 & $1 / 2$ & 0 & 0 & $1 / 2$ \\
\hline 8 & 0 & $1 / 2$ & $1 / 2$ & 0 \\
\hline 9 & 0 & $1 / 2$ & 0 & $1 / 2$ \\
\hline 10 & 0 & 0 & $1 / 2$ & $1 / 2$ \\
\hline 11 & $5 / 8$ & $1 / 8$ & $1 / 8$ & $1 / 8$ \\
\hline 12 & $1 / 8$ & $5 / 8$ & $1 / 8$ & $1 / 8$ \\
\hline 13 & $1 / 8$ & $1 / 8$ & $5 / 8$ & $1 / 8$ \\
\hline 14 & $1 / 8$ & $1 / 8$ & $1 / 8$ & $5 / 8$ \\
\hline 15 & $1 / 4$ & $1 / 4$ & $1 / 4$ & $1 / 4$ \\
\hline
\end{tabular}

All the formulated medium had the moisture level adjusted to $50 \%$ according to the initial moisture.

Oklahoma, USA) was used for the experimental design, data analysis, and model building.

\subsection{Determination of lipase activity}

Lipase activity was measured in a reaction mixture consisting of an emulsion composed of pure olive oil, gum arabic solution, phosphate buffer and $1 \mathrm{~mL}$ of enzyme solution. The released fatty acids were titrated with $\mathrm{NaOH}(0.05 \mathrm{M})$. One unit of lipase activity $(\mathrm{U})$ was defined as the amount of lipase required to liberate $1 \mu \mathrm{mol}$ of fatty acid per minute per $1 \mathrm{~mL}$ of the supernatant under the described conditions (Burkert et al., 2004).

\subsection{Determination of endo- $\beta-1,4-$ glucanase activity}

The CMCase activity was measured using carboxymethyl cellulose as the substrate in citrate buffer. The reducing sugars in the samples were quantified at $540 \mathrm{~nm}$ using the dinitrosalicylic acid (DNS) method according to Miller (1959). One unit of CMCase activity was defined as the amount of enzyme necessary to produce $1 \mu \mathrm{mol}$ of glucose per minute under the assay conditions.

\subsection{Determination of $\alpha$-amylase activity}

The $\alpha$-amylase activity was measured using starch as the substrate in sodium acetate buffer. After hydrolysis, the reducing sugars were quantified at $540 \mathrm{~nm}$ using the DNS method (Miller, 1959). One unit of $\alpha$-amylase activity was defined as the amount of enzyme necessary to produce $1 \mu \mathrm{mol}$ of glucose per minute under the assay conditions.

\subsection{Determination of $\beta$-glucosidase activity}

The $\beta$-glucosidase activity was determined based on the release of $p$-nitrophenol from the enzymatic hydrolysis of $p$-nitrophenyl- $\beta$-d-glucopyranoside ( $p$ NPG) (Sigma-Aldrich, São 
Paulo State, Brazil. Hydrolysis was determined by monitoring the release of $p$-nitrophenol at $410 \mathrm{~nm}$ with reference to a standard curve prepared using $p$-nitrophenol. One unit of $\beta$-glucosidase activity was defined as the amount of enzyme required to release of $1 \mu \mathrm{mol}$ of $p$-nitrophenol under the assay conditions described (Figueira et al., 2013).

\section{Results and discussion}

\subsection{Enzyme production using formulations containing different proportions of agroindustrial wastes}

During the SSF of A. niger LBA 02 on different agroindustrial wastes and their mixtures, the enzymatic activities of lipase, CMCase, $\alpha$-amylase, and $\beta$-glucosidase were investigated in the crude extract (Table 2). The highest lipase and CMCase activities were detected at $48 \mathrm{~h}$ fermentation, while the activity peaks for $\alpha$-amylase and $\beta$-glucosidase were observed at 72 and $96 \mathrm{~h}$, respectively. Enzyme secretion was strongly induced by the agroindustrial wastes and their formulations. With regards to the maximum values of enzyme activity, lipase production reached 323 and $319 \mathrm{U} \mathrm{g}^{-1}$ at $48 \mathrm{~h}$ in runs 3 and 5, respectively, in which cottonseed meal (run 3) and equal proportions of wheat bran and soybean meal (run 5) were used as fermentation substrates.

The formulation in run 5 also resulted in maximum CMCase activity, reaching $10 \mathrm{U} \mathrm{g}^{-1}$ at $48 \mathrm{~h}$, followed by wheat bran (run 1) as the fermentation substrate producing $9 \mathrm{U} \mathrm{g}^{-1}$. Wheat bran as the sole substrate (run 1) was the most adequate medium for $\alpha$-amylase production $\left(18 \mathrm{U} \mathrm{g}^{-1}\right.$ at $72 \mathrm{~h}$ ) followed by formulations containing mixed substrates, such as wheat bran and soybean meal in equal proportions (run $5-14 \mathrm{U} \mathrm{g}^{-1}$ at $24 \mathrm{~h}$ ) and the quaternary mixture of wheat bran (5/8), soybean meal (1/8), cottonseed meal (1/8), and orange peel (1/8) (run $11-15 \mathrm{U} \mathrm{g}^{-1}$ at $24 \mathrm{~h}$ ). For $\beta$-glucosidase, the maximum production was observed when the quaternary mixture of wheat bran (1/8), soybean meal (5/8), cottonseed meal (1/8), and orange peel (1/8) (run 12) was used as the fermentation substrate, reaching $15 \mathrm{Ug} \mathrm{g}^{-1}$ at $96 \mathrm{~h}$. This was followed by soybean meal alone (run 2), and the binary mixtures of wheat bran (1/2) with soybean meal (1/2) (run 5), and wheat bran $(1 / 2)$ with cottonseed meal (1/2) (run 6), which resulted in $\beta$-glucosidase levels of up to $10 \mathrm{U} \mathrm{g}^{-1}$ at $72 \mathrm{~h}$.

Recent studies about lipase production using agroindustrial wastes usually apply oil-rich substrates and/or oil supplementation in order to stimulate the enzyme production. Salgado et al. (2014), Toscano et al. (2013), Coradi et al. (2013) and Ferraz et al. (2012) reported the positive impact of lipids in inducing lipase production. In accordance with the literature data, this study reported the highest lipase activity using the waste with the highest lipid content; namely, cottonseed meal (run 3). According to the centesimal compositions of the agroindustrial wastes used in this work (as reported by Ohara et al. (2015)), cottonseed meal had the highest lipid content (8.36\%), and the medium composed solely of this substrate produced the highest lipase activity $\left(323 \mathrm{U} \mathrm{g}^{-1}\right)$ after $48 \mathrm{~h}$ fermentation. Interestingly, the mixture composed of equal proportions of wheat bran and soybean meal (run 5) also produced a high level of lipase (319 $\left.\mathrm{U} \mathrm{g}^{-1}\right)$, presenting an alternative to producing this enzyme without the need of a substrate with a high lipid content.

Bansal et al. (2012) tested several agricultural and kitchen wastes for cellulases production by $A$. niger under SSF. Comparing all the substrates tested, wheat bran was the most suitable, producing yields of CMCase, filter paperase (FPase), and $\beta$-glucosidase of 310,17 , and $33 \mathrm{U} \mathrm{g}^{-1}$, respectively. Das et al. (2013) and Sahnoun et al. (2015) also reported the advantages of using wheat bran and soybean meal as substrates for endoglucanase, $\beta$-glucosidase, FPase, and $\alpha$-amylase production. Similar to these data, our work presented high cellulase production when wheat bran and soybean were used as substrates, and the binary mixture of wheat bran (1/2) with soybean meal (1/2) (run 5) was favorable for CMCase, $\beta$-glucosidase, and $\alpha$-amylase production. The use of cheap and waste cellulosic residues as inducers for

Table 2. Results for lipase, CMCase, $\alpha$-amylase and $\beta$-glucosidase activities during the fermentation times using the simplex-lattice mixture design.

\begin{tabular}{|c|c|c|c|c|c|c|c|c|c|c|c|c|}
\hline \multirow{3}{*}{ Run } & \multicolumn{3}{|c|}{ Lipase } & \multicolumn{3}{|c|}{ CMCase } & \multicolumn{3}{|c|}{ a-amylase } & \multicolumn{3}{|c|}{$\beta$-glucosidase } \\
\hline & \multicolumn{3}{|c|}{$\left(\mathrm{U} \mathrm{g}^{-1}\right)$} & \multicolumn{3}{|c|}{$\left(\mathrm{U} \mathrm{g}^{-1}\right)$} & \multicolumn{3}{|c|}{$\left(\mathrm{U} \mathrm{g}^{-1}\right)$} & \multicolumn{3}{|c|}{$\left(\mathrm{U} \mathrm{g}^{-1}\right)$} \\
\hline & $24 \mathrm{~h}$ & $48 \mathrm{~h}$ & $72 \mathrm{~h}$ & $24 \mathrm{~h}$ & $48 \mathrm{~h}$ & $72 \mathrm{~h}$ & $48 \mathrm{~h}$ & $72 \mathrm{~h}$ & $96 \mathrm{~h}$ & $48 \mathrm{~h}$ & $72 \mathrm{~h}$ & $96 \mathrm{~h}$ \\
\hline 1 & $17 \pm 6$ & $168 \pm 13$ & $81 \pm 6$ & $5 \pm 0$ & $9 \pm 0$ & $7 \pm 0$ & $17 \pm 1$ & $18 \pm 1$ & $17 \pm 1$ & $7 \pm 1$ & $7 \pm 1$ & $7 \pm 0$ \\
\hline 2 & $44 \pm 6$ & $259 \pm 13$ & $255 \pm 6$ & $4 \pm 0$ & $7 \pm 0$ & $5 \pm 0$ & $8 \pm 0$ & $2 \pm 0$ & $3 \pm 0$ & $5 \pm 0$ & $11 \pm 0$ & $8 \pm 0$ \\
\hline 3 & $35 \pm 6$ & $323 \pm 13$ & $159 \pm 13$ & $4 \pm 0$ & $7 \pm 0$ & $6 \pm 0$ & $3 \pm 0$ & $7 \pm 0$ & $4 \pm 1$ & $5 \pm 0$ & $5 \pm 0$ & $6 \pm 0$ \\
\hline 4 & $81 \pm 6$ & $140 \pm 13$ & $81 \pm 6$ & $1 \pm 0$ & $1 \pm 0$ & $1 \pm 0$ & $1 \pm 1$ & $2 \pm 0$ & $2 \pm 0$ & $0 \pm 0$ & $0 \pm 0$ & $0 \pm 0$ \\
\hline 5 & $58 \pm 0$ & $319 \pm 32$ & $228 \pm 13$ & $5 \pm 0$ & $10 \pm 1$ & $7 \pm 0$ & $14 \pm 0$ & $3 \pm 0$ & $11 \pm 0$ & $9 \pm 0$ & $10 \pm 1$ & $9 \pm 1$ \\
\hline 6 & $63 \pm 6$ & $209 \pm 19$ & $113 \pm 13$ & $5 \pm 0$ & $6 \pm 0$ & $6 \pm 0$ & $12 \pm 1$ & $14 \pm 1$ & $13 \pm 1$ & $4 \pm 0$ & $11 \pm 1$ & $10 \pm 0$ \\
\hline 7 & $67 \pm 13$ & $17 \pm 6$ & $31 \pm 13$ & $4 \pm 0$ & $6 \pm 0$ & $5 \pm 0$ & $5 \pm 0$ & $2 \pm 0$ & $5 \pm 0$ & $1 \pm 0$ & $4 \pm 0$ & $4 \pm 0$ \\
\hline 8 & $76 \pm 0$ & $200 \pm 6$ & $218 \pm 6$ & $5 \pm 0$ & $6 \pm 0$ & $5 \pm 0$ & $6 \pm 0$ & $7 \pm 1$ & $4 \pm 0$ & $9 \pm 0$ & $9 \pm 0$ & $6 \pm 1$ \\
\hline 9 & $44 \pm 6$ & $81 \pm 6$ & $159 \pm 13$ & $3 \pm 0$ & $6 \pm 0$ & $5 \pm 0$ & $7 \pm 0$ & $3 \pm 0$ & $7 \pm 1$ & $2 \pm 0$ & $9 \pm 1$ & $6 \pm 1$ \\
\hline 10 & $49 \pm 0$ & $85 \pm 13$ & $122 \pm 0$ & $3 \pm 0$ & $6 \pm 0$ & $6 \pm 0$ & $5 \pm 0$ & $1 \pm 0$ & $1 \pm 0$ & $3 \pm 0$ & $6 \pm 1$ & $7 \pm 0$ \\
\hline 11 & $26 \pm 6$ & $108 \pm 6$ & $145 \pm 19$ & $5 \pm 0$ & $8 \pm 0$ & $7 \pm 0$ & $15 \pm 1$ & $13 \pm 1$ & $14 \pm 1$ & $2 \pm 0$ & $9 \pm 0$ & $7 \pm 0$ \\
\hline 12 & $85 \pm 13$ & $85 \pm 0.0$ & $214 \pm 13$ & $5 \pm 0$ & $7 \pm 0$ & $6 \pm 0$ & $8 \pm 1$ & $7 \pm 1$ & $8 \pm 0$ & $3 \pm 0$ & $6 \pm 0$ & $15 \pm 2$ \\
\hline 13 & $76 \pm 0$ & $81 \pm 6$ & $168 \pm 13$ & $5 \pm 0$ & $7 \pm 0$ & $6 \pm 0$ & $6 \pm 0$ & $4 \pm 0$ & $5 \pm 0$ & $4 \pm 0$ & $4 \pm 0$ & $7 \pm 0$ \\
\hline 14 & $104 \pm 0$ & $90 \pm 6$ & $72 \pm 6$ & $3 \pm 0$ & $6 \pm 0$ & $5 \pm 0$ & $3 \pm 1$ & $5 \pm 0$ & $8 \pm 1$ & $1 \pm 0$ & $3 \pm 0$ & $8 \pm 1$ \\
\hline 15 & $90 \pm 6$ & $136 \pm 6$ & $131 \pm 0$ & $5 \pm 0$ & $8 \pm 0$ & $7 \pm 0$ & $11 \pm 0$ & $3 \pm 0$ & $10 \pm 1$ & $5 \pm 0$ & $8 \pm 1$ & $9 \pm 0$ \\
\hline
\end{tabular}

Results are presented as the mean of enzyme activities $(n=3) \pm$ standard deviation. 
cellulase production has also been reported by Behera \& Ray (2016), Bansal et al. (2012) and Sahnoun et al. (2015).

\subsection{Model fitting and regression analysis}

The coefficient of determination $R^{2}$ and the $F$ test (ANOVA) were used to verify the quality of fit of the models. Table 3 lists the models, with corresponding $R^{2}$ and adjusted $R^{2}$ of the regression equations for the responses as well as the corresponding $F$-ratio and $p$-values for each term in the predicted regression equations. The high $R^{2}$ values, which were above 0.86 , indicate that all response functions adequately fit the experimental data, and the models can be used to predict lipase, CMCase, $a$-amylase and $\beta$-Glucosidase production. The predicted regression equations represent the model with the significant factors for enzyme production (Table 3). The negative and positive terms represent antagonistic and synergistic effects, respectively, indicating the influence of binary and ternary mixtures on enzyme production. At $48 \mathrm{~h}$, the binary interaction between wheat bran and soybean meal $\left(x_{1} x_{2}\right)$ demonstrated a synergistic effect and positively influenced the lipase production. On the other hand, the ternary interaction $\left(x_{1} x_{2} x_{3}\right)$ showed the highest negative effect on lipase production. Generally, the component cottonseed meal $\left(x_{3}\right)$ and the mixtures containing it positively influenced the lipase production by $A$. niger LBA 02 . Synergistic and significant effects $(\mathrm{P}<0.05)$ on $\mathrm{CMCase}$ production were detected for the ternary mixtures containing wheat bran $\left(x_{1}\right)$ cottonseed meal $\left(x_{3}\right)$, and orange peel $\left(x_{4}\right)$, as well as in formulations composed of soybean meal $\left(x_{2}\right)$ cottonseed meal $\left(x_{3}\right)$, and orange peel $\left(x_{4}\right)$, at $48 \mathrm{~h}$.

Table 3. Models, $R^{2}$, adjusted $R^{2}$, and probability values for the final reduced models (component proportion) of lipase, CMCase, $\alpha$-amylase and $\beta$-glucosidase activities.

\begin{tabular}{|c|c|c|c|c|}
\hline Response & \multicolumn{4}{|c|}{ ANOVA } \\
\hline $\begin{array}{l}\text { Lipase activity } \\
\left(\mathrm{U} \mathrm{g}^{-1}\right)\end{array}$ & $F$ calculated & $F$ tabulated & $R^{2}$ & $p$-value \\
\hline \multirow[t]{2}{*}{$24 \mathrm{~h}$} & 36.32 & 2.37 & 0.96 & $<0.001$ \\
\hline & $\mathrm{Y}=16.8 x_{1}+44.2 x_{2}+3$ & $\begin{array}{r}x_{1} x_{2}+152.6 x \\
56\end{array}$ & $x_{2} x_{3}-$ & $-1352.4 x_{1} x_{3} x_{4}+$ \\
\hline $48 \mathrm{~h}$ & 13.81 & 2.37 & 0.86 & $<0.001$ \\
\hline $72 \mathrm{~h}$ & \multicolumn{4}{|c|}{$Y=78.0 x_{1}+255.3 x_{2}+165.3 x_{3}+78.2 x_{4}+221.8 x_{1} x_{2}-191.3 x_{1} x_{4}+3711.2 x_{1} x_{2} x_{3}-3899.2 x_{2} x_{3} x_{4}$} \\
\hline $\begin{array}{l}\text { CMCase activity } \\
\left(\mathrm{U} \mathrm{g} \mathrm{g}^{-1}\right)\end{array}$ & $F$ calculated & $F$ tabulated & $R^{2}$ & $p$-value \\
\hline $24 \mathrm{~h}$ & 37.69 & 2.02 & 0.91 & $<0.001$ \\
\hline \multirow[t]{2}{*}{$72 \mathrm{~h}$} & 158.70 & 1.82 & 0.98 & $<0.001$ \\
\hline & \multicolumn{4}{|c|}{$\mathrm{Y}=7.2 x_{1}+5.3 x_{2}+5.5 x_{3}+0.9 x_{4}+4.1 x_{1} x_{2}+5.5 x_{1} x_{4}+8.7 x_{2} x_{4}+9.3 x_{3} x_{4}-50.2 x_{1} x_{2} x_{3}+71.6 x_{2} x_{3} x_{4}$} \\
\hline $\begin{array}{c}\alpha \text {-amylase activity } \\
\left(\mathrm{U} \mathrm{g}^{-1}\right)\end{array}$ & $F$ calculated & $F$ tabulated & $R^{2}$ & $p$-value \\
\hline \multirow[t]{2}{*}{$48 \mathrm{~h}$} & 113.77 & 1.75 & 0.98 & $<0.001$ \\
\hline & \multicolumn{4}{|c|}{$\begin{array}{c}\mathrm{Y}=16.4 x_{1}+8.2 x_{2}+2.5 x_{3}+1.4 x_{4}+7.0 x_{1} x_{2}+10.7 x_{1} x_{3}-17.6 x_{1} x_{4}+3.7 x_{2} x_{3}+10.0 x_{2} x_{4}+10.9 x_{3} x_{4}+172.8 x_{1} x_{2} x_{3}+101.0 x_{1} x_{2} x_{4}+ \\
167.9 x_{1} x_{3} x_{4}-410.5 x_{2} x_{3} x_{4}\end{array}$} \\
\hline $72 \mathrm{~h}$ & 44.23 & 1.81 & 0.93 & $<0.001$ \\
\hline $96 \mathrm{~h}$ & $\begin{array}{c}\mathrm{Y}=18.6 x_{1}+2.7 x_{2} \\
244.17\end{array}$ & $x_{2}-32.8 x_{1} x$ & +603 & $\begin{aligned}- & 233.5 x_{2} x_{3} x_{4} \\
< & <0.001\end{aligned}$ \\
\hline $72 \mathrm{~h}$ & $\mathrm{Y}=7$ & $0.4 x_{4}+16.5 x$ & $x_{2} x_{4}+$ & \\
\hline \multirow[t]{2}{*}{$96 \mathrm{~h}$} & 44.62 & 1.81 & 0.93 & $<0.001$ \\
\hline & \multicolumn{4}{|c|}{$\mathrm{Y}=7.3 x_{1}+7.6 x_{2}+5.6 x_{3}+0.6 x_{4}+6.4 x_{1} x_{2}+14.5 x_{1} x_{3}+6.9 x_{2} x_{4}+16.7 x_{3} x_{4}+400.6 x_{1} x_{2} x_{4}-680.8 x_{1} x_{3} x_{4}+423.4 x_{2} x_{3} x_{4}$} \\
\hline
\end{tabular}


The interaction $x_{1} x_{2} x_{3}$ (wheat bran/soybean meal/cottonseed meal) showed the highest antagonistic effect and resulted in a decrease of CMCase activity at 48 and $72 \mathrm{~h}$.

The most prominent and positive effects on $\beta$-glucosidase production were detected at $96 \mathrm{~h}$, as demonstrated by the regression coefficients of the interactions $x_{1} x_{2} x_{4}$ (wheat bran/soybean meal/orange peel) and $x_{2} x_{3} x_{4}$ (soybean meal/cottonseed meal/orange peel). Orange peel is a waste naturally rich in complex polysaccharides pectin, cellulose, and hemicellulose) (Mantzouridou et al., 2015), and its presence in different formulations showed a positive effect on cellulase production (CMCase and $\beta$-glucosidase). In the study of $\alpha$-amylase production, the ternary mixture of wheat bran $\left(x_{1}\right)$ soybean meal $\left(x_{2}\right)$, and orange peel $\left(x_{3}\right)$ showed the highest and significant synergistic effect, whereas the other ternary mixtures $\left(x_{1} x_{3} x_{4}\right.$ and $\left.x_{2} x_{3} x_{4}\right)$ presented negative effects and resulted in decreases of the enzyme activity at $72 \mathrm{~h}$.

\subsection{Interpretation of contour plots}

The two-dimensional ternary plots and contour area graphs evaluate the interactions of any three of the factors in terms of their effect on enzyme production. The mixture contour plots for lipase, CMCase, $\alpha$-amylase, and $\beta$-glucosidase are presented in Figures 1 and 2. The tested enzymes showed that for each fermentation time, there was a most suitable formulation for
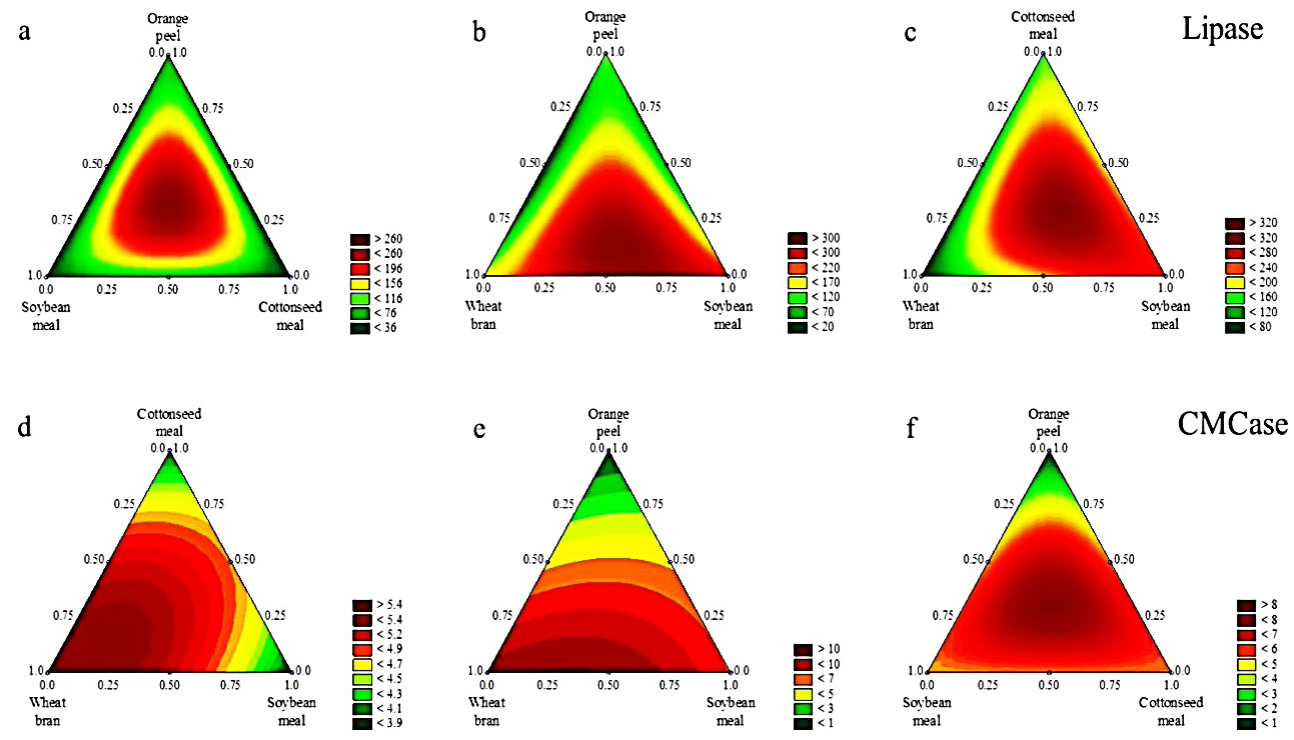

Figure 1. Mixture contour plots for lipase ( $a, b, c)$ and CMCase ( $d, e, f)$ production by A. niger LBA 02 under solid state fermentation for 24 (a, d), $48(b, e)$ and $72 \mathrm{~h}(\mathrm{c}, \mathrm{f})$ as a function of significant $(\mathrm{p}<0.05)$ interaction effects of ternary mixtures of agroindustrial wastes.

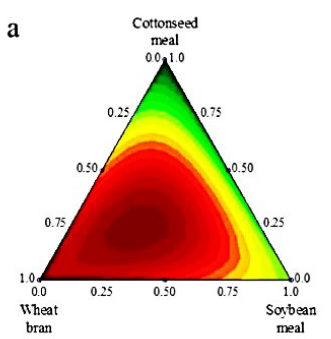

d

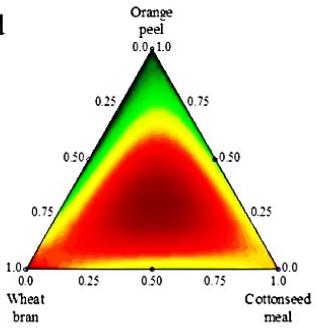

b

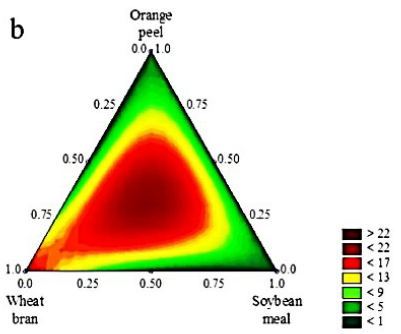

e

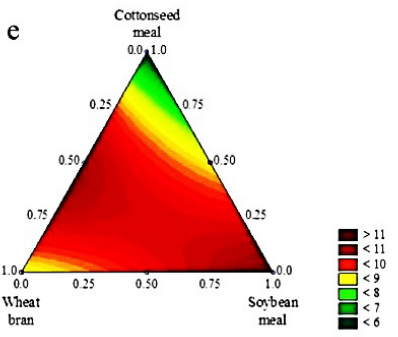

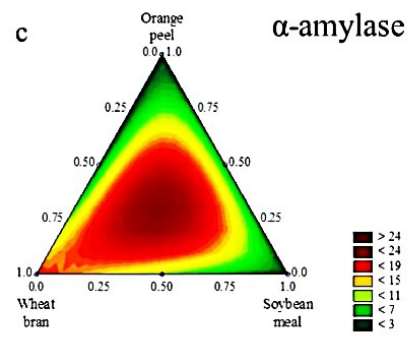

$\mathrm{f}$

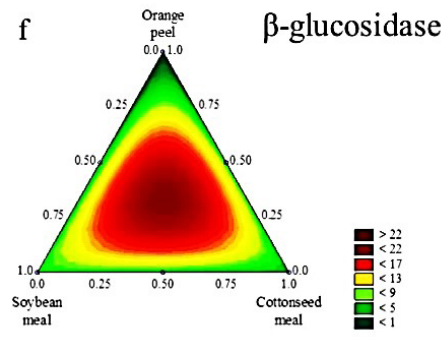

Figure 2. Mixture contour plots for $\alpha$-amylase $(a, b, c)$ and $\beta$-glucosidase $(\mathrm{d}, \mathrm{e}, \mathrm{f})$ production by $A$. niger LBA 02 under solid state fermentation for $48(\mathrm{a}, \mathrm{d}), 72(\mathrm{~b}, \mathrm{e})$ and $96 \mathrm{~h}(\mathrm{c}, \mathrm{f})$ as a function of significant $(\mathrm{p}<0.05)$ interaction effects of ternary mixtures of agroindustrial wastes. 
maximum activity. However, for the simultaneous production of enzymes, some formulations presented advantages on a global view. For example, for a fixed fermentation time of $48 \mathrm{~h}$, the formulation of orange peel $(1 / 3)$, wheat bran $(1 / 3)$, and soybean meal (1/3) resulted in the highest production of lipase $\left(>300 \mathrm{U} \mathrm{g} \mathrm{g}^{-1}\right)$ (Figure 1b), CMCase $\left(>10 \mathrm{U} \mathrm{g}^{-1}\right)$ (Figure 1e), and $a$-amylase (>22 $\mathrm{U} \mathrm{g}^{-1}$ ) (Figure $2 \mathrm{~b}$ ). Taking into consideration the substrate formulation only, the ternary mixture of wheat bran (1/3), soybean meal (1/3), and cottonseed meal (1/3) was the most versatile, showing production of CMCase (Figure 1d) and $\alpha$-amylase (Figure $2 \mathrm{a}$ ) at $24 \mathrm{~h}$, lipase at $72 \mathrm{~h}$ (Figure 1c), and $\beta$-glucosidase at $48 \mathrm{~h}$ (Figure 2e).

\section{Conclusions}

The use of statistical mixture design for enzyme production has potential application in industrial processes, owing to the versatility and sustainability of the method that can reach high simultaneous production of enzymes in a single process based on a blend of agroindustrial wastes under SSF. The highest enzyme activities were $323 \mathrm{U} \mathrm{g}^{-1}$ for lipase, $10 \mathrm{U} \mathrm{g}^{-1}$ for CMCase, $18 \mathrm{U} \mathrm{g}^{-1}$ for $\alpha$-amylase and $15 \mathrm{U} \mathrm{g}^{-1}$ for $\beta$-glucosidase. The ternary mixture of wheat bran (1/3), soybean meal (1/3), and cottonseed meal $(1 / 3)$ was the most versatile, showing production of CMCase $\left(>5 \mathrm{U} \mathrm{g}^{-1}\right)$ and $\alpha$-amylase $\left(>8 \mathrm{U} \mathrm{g}^{-1}\right)$ at $24 \mathrm{~h}$, lipase $\left(>320 \mathrm{U} \mathrm{g}^{-1}\right)$ at $72 \mathrm{~h}$, and $\beta$-glucosidase $\left(>10 \mathrm{U} \mathrm{g}^{-1}\right)$ at $48 \mathrm{~h}$.

\section{References}

Bansal, N., Tewari, R., Soni, R., \& Soni, S. K. (2012). Production of cellulases from Aspergillus niger NS-2 in solid state fermentation on agricultural and kitchen waste residues. Waste Management (New York, N.Y.), 32(7), 1341-1346. PMid:22503148. http://dx.doi. org/10.1016/j.wasman.2012.03.006.

Behera, S. S., \& Ray, R. C. (2016). Solid state fermentation for production of microbial cellulases: recent advances and improvement strategies. International Journal of Biological Macromolecules, 86, 656-669. PMid:26601764. http://dx.doi.org/10.1016/j.ijbiomac.2015.10.090.

Burkert, J. F. D. M., Maugeri, F., \& Rodrigues, M. I. (2004). Optimization of extracellular lipase production by Geotrichum sp. using factorial design. Bioresource Technology, 91(1), 77-84. PMid:14585624. http:// dx.doi.org/10.1016/S0960-8524(03)00152-4.

Castro, R. J. S., \& Sato, H. H. (2013). Synergistic effects of agroindustrial wastes on simultaneous production of protease and $\alpha$-amylase under solid state fermentation using a simplex centroid mixture design. Industrial Crops and Products, 49, 813-821. http://dx.doi. org/10.1016/j.indcrop.2013.07.002.

Castro, R. J. S., \& Sato, H. H. (2015). Enzyme production by solid state fermentation: general aspects and an analysis of the physicochemical characteristics of substrates for agro-industrial wastes valorization. Waste and Biomass Valorization, 6(6), 1085-1093. http://dx.doi. org/10.1007/s12649-015-9396-x.

Chen, H. Z., Liu, Z. H., \& Dai, S. H. (2014). A novel solid state fermentation coupled with gas stripping enhancing the sweet sorghum stalk conversion performance for bioethanol. Biotechnology for Biofuels, 7(1), 53. PMid:24713041. http://dx.doi.org/10.1186/1754-6834-7-53.

Colla, L. M., Rizzardi, J., Pinto, M. H., Reinehr, C. O., Bertolin, T. E., \& Costa, J. A. V. (2010). Simultaneous production of lipases and biosurfactants by submerged and solid-state bioprocesses. Bioresource
Technology, 101(21), 8308-8314. PMid:20580228. http://dx.doi. $\operatorname{org} / 10.1016 /$ j.biortech.2010.05.086.

Coradi, G. V., Visitação, V. L., Lima, E. A., Saito, L. Y. T., Palmieri, D. A., Takita, M., Oliva, P. O. No., \& Lima, V. M. G. (2013). Comparing submerged and solid-state fermentation of agro-industrial residues for the production and characterization of lipase by Trichoderma harzianum. Annals of Microbiology, 63(2), 533-540. http://dx.doi. org/10.1007/s13213-012-0500-1.

Damaso, M. C. T., Passianoto, M. A., Freitas, S. C. D., Freire, D. M. G., Lago, R. C. A., \& Couri, S. (2008). Utilization of agroindustrial residues for lipase production by solid-state fermentation. Brazilian Journal of Microbiology, 39(4), 676-681. PMid:24031288. http:// dx.doi.org/10.1590/S1517-83822008000400015.

Dar, G. H., Kamili, A. N., Nazir, R., Bandh, S. A., Jan, T. R., \& Chishti, M. Z. (2015). Enhanced production of a-amylase by Penicillium chrysogenum in liquid culture by modifying the process parameters. Microbial Pathogenesis, 88, 10-15. PMid:26220910. http://dx.doi. org/10.1016/j.micpath.2015.07.016.

Das, A., Paul, T., Halder, S. K., Jana, A., Maity, C., Das Mohapatra, P. K., Pati, B. R., \& Mondal, K. C. (2013). Production of cellulolytic enzymes by Aspergillus fumigatus ABK9 in wheat bran-rice straw mixed substrate and use of cocktail enzymes for deinking of waste office paper pulp. Bioresource Technology, 128, 290-296. PMid:23196251. http://dx.doi.org/10.1016/j.biortech.2012.10.080.

Devi, M. C., \& Kumar, M. S. (2017). Production, optimization and partial purification of cellulase by Aspergillus niger fermented with paper and timber sawmill industrial wastes. Journal of Microbiology and Biotechnology Research, 2(1), 120-128.

Ferraz, L. R., Oliveira, D. D. S., Silva, M. F., Rigo, E., Di Luccio, M., Oliveira, J. V., Oliveira, D., \& Treichel, H. (2012). Production and partial characterization of multifunctional lipases by Sporobolomyces ruberrimus using soybean meal, rice meal and sugarcane bagasse as substrates. Biocatalysis and Agricultural Biotechnology, 1(3), 243-252. http://dx.doi.org/10.1016/j.bcab.2012.03.008.

Figueira, J. A., Sato, H. H., \& Fernandes, P. (2013). Establishing the feasibility of using $\beta$-glucosidase entrapped in Lentikats and in sol-gel supports for cellobiose hydrolysis. Journal of Agricultural and Food Chemistry, 61(3), 626-634. PMid:23294439. http://dx.doi. org/10.1021/jf304594s.

Mahadik, N. D., Puntambekar, U. S., Bastawde, K. B., Khire, J. M., \& Gokhale, D. V. (2002). Production of acidic lipase by Aspergillus niger in solid state fermentation. Process Biochemistry, 38(5), 715721. http://dx.doi.org/10.1016/S0032-9592(02)00194-2.

Mantzouridou, F. T., Paraskevopoulou, A., \& Lalou, S. (2015). Yeast flavour production by solid state fermentation of orange peel waste. Biochemical Engineering Journal, 101, 1-8. http://dx.doi.org/10.1016/j. bej.2015.04.013.

Martins, S., Mussatto, S. I., Martínez-Avila, G., Montañez-Saenz, J., Aguilar, C. N., \& Teixeira, J. A. (2011). Bioactive phenolic compounds: production and extraction by solid-state fermentation. A review. Biotechnology Advances, 29(3), 365-373. PMid:21291993. http:// dx.doi.org/10.1016/j.biotechadv.2011.01.008.

Miller, G. L. (1959). Use of dinitrosalicylic acid reagent for determination of reducing sugar. Analytical Chemistry, 31(3), 426-428. http://dx.doi. org/10.1021/ac60147a030.

Ohara, A., Castro, R. J. S., Nishide, T. G., Dias, F. F. G., Bagagli, M. P., \& Sato, H. H. (2015). Invertase production by Aspergillus niger under solid state fermentation: Focus on physical-chemical parameters, synergistic and antagonistic effects using agro-industrial wastes. Biocatalysis and Agricultural Biotechnology, 4(4), 645-652. http:// dx.doi.org/10.1016/j.bcab.2015.06.008. 
Sahnoun, M., Kriaa, M., Elgharbi, F., Ayadi, D. Z., Bejar, S., \& Kammoun, R. (2015). Aspergillus oryzae S2 alpha-amylase production under solid state fermentation: Optimization of culture conditions. International Journal of Biological Macromolecules, 75, 73-80. PMid:25617840. http://dx.doi.org/10.1016/j.ijbiomac.2015.01.026.

Salgado, J. M., Abrunhosa, L., Venâncio, A., Domínguez, J. M., \& Belo, I. (2014). Integrated use of residues from olive mill and winery for lipase production by solid state fermentation with Aspergillus sp. Applied Biochemistry and Biotechnology, 172(4), 1832-1845. PMid:24276916. http://dx.doi.org/10.1007/s12010-013-0613-4.

Thomas, L., Larroche, C., \& Pandey, A. (2013). Current developments in solid-state fermentation. Biochemical Engineering Journal, 81, 146-161. http://dx.doi.org/10.1016/j.bej.2013.10.013.
Toscano, L., Montero, G., Stoytcheva, M., Gochev, V., Cervantes, L., Campbell, H., Zlatev, R., Valdez, B., Pérez, C., \& Gil-Samaniego, M. (2013). Lipase production through solid-state fermentation using agro-industrial residues as substrates and newly isolated fungal strains. Biotechnology, Biotechnological Equipment, 27(5), 4074-4077. http://dx.doi.org/10.5504/BBEQ.2012.0145.

Treichel, H., de Oliveira, D., Mazutti, M. A., Di Luccio, M., \& Oliveira, J. V. (2010). A review on microbial lipases production. Food and Bioprocess Technology, 3(2), 182-196. http://dx.doi.org/10.1007/ s11947-009-0202-2.

Xue, D. S., Wang, J. B., \& Yao, S. J. (2015). High production of $\beta$-glucosidase from a marine Aspergillus niger immobilized on towel gourd vegetable sponges. Chinese Chemical Letters, 26(8), 1011-1015. http://dx.doi. org/10.1016/j.cclet.2015.05.019. 